\title{
The use of resorcine adhesive in repairing osteochondral's defect in knees of rabbits ${ }^{1}$
}

\author{
O uso do adesivo de resorcina na reparação de \\ defeito osteocondral em joelhos de coelhos
}

\author{
Augusto Ken Sakihama², Djalma José Fagundes ${ }^{3}$, Celso Massaschi Inouye ${ }^{4}$, Ricardo Dutra Aydos ${ }^{5}$, Yara Juliano ${ }^{6}$, Juliano \\ Coelho Arakaki ${ }^{7}$, Maçanori Odashiro ${ }^{8}$, Paulo de Tarso Camilo de Carvalho 9.
}

1. Research from Surgery and Experimentation Post-Graduate Program of São Paulo Federal University (UNIFESP) - São Paulo, Brazil.

2. PhD, Associate Professor of the Department of Physiotherapy, University for Development of the State and the Pantanal Region (UNIDERP), Campo Grande, Mato Grosso do Sul, Brazil.

3. PhD, Associate Professor of the Department of Surgery, UNIFESP, Brazil.

4. PhD, Full Professor of Department of Surgery, Federal University of Mato Grosso do Sul (UFMS), Brazil.

5. PhD, Associate Professor of the Department of Surgery, UFMS, Brazil.

6. PhD, Associate Professor of the Department of Preventive Medicine, UNIFESP, Brazil.

7. Master, Associate Professor of the Department of Surgery, UFMS, Brazil.

8. Associate Professor of the Department of Surgery, UFMS, Brazil.

9. $\mathrm{PhD}$, Associate Professor of the Department of Physiotherapy, UNIDERP, Brazil

\begin{abstract}
Purpose: To study the morphology of the articulation of the knee of rabbits after the repairing of the defect osteochondral standardized with resorcina adhesive or metallic synthesis. Methods: The procedure was to the creation of the defect osteochondral in femoral medial condylus of the knee of 80 rabbits, The animals were distributed in two groups with continuations of 7 and 42 days and submitted to the technique $\mathrm{G}$ (resection and retreat of the fragment osteochondral of the femoral medial condylus and relocation with resorcina adhesive), technique $\mathrm{S}$ (resection and retreat of the fragment osteochondral of the femoral medial condylus and relocation and metallic synthesis) or technique $\mathrm{C}$ (resection and retreat of the fragment osteochondral of the femoral medial condylus, leaving the empty standard defect the control). It was Made clinical study, radiographic, macroscopic and histological in two groups. Results: the resorcina adhesive provokes: necrosis of the fragment osteochondral in $100 \%$ and $95 \%$, degeneration $90 \%$ and $100 \%$, free body in $80 \%$ and $65 \%$ respectively in the group I and II; compared with the metallic synthesis that it presented: necrosis in $25 \%$ and $35 \%$, degeneration $25 \%$ and $35 \%$, free body in $35 \%$ and $10 \%$ respectively in the group I and II. Conclusion: the resorcinol adhesive, related with the necrosis, cartilaginous degeneration and detachment of the fragment osteochondral lives frequently that the metallic synthesis
\end{abstract}

Key words: Adhesives. Knee. Rabbits. Osteochondral.

\section{RESUMO}

Objetivo: Estudar a morfologia da articulação do joelho de coelhos após a reparação de um defeito osteocondral padronizado com adesivo de resorcina ou síntese metálica. Métodos: Procedeu-se à criação de um defeito osteocondral em côndilo femoral medial do joelho de 80 coelhos. Os animais foram distribuídos em dois grupos com seguimentos de 7 e 42 dias e submetidos à técnica $\mathrm{G}$ (ressecção e retirada do fragmento osteocondral do côndilo femoral medial e recolocação com adesivo de resorcina), técnica $\mathrm{S}$ (ressecção e retirada do fragmento osteocondral do côndilo femoral medial e recolocação e síntese metálica) ou técnica C (ressecção e retirada do fragmento osteocondral do côndilo femoral medial, deixando o defeito padrão vazio como controle). Fez-se estudo clínico, radiográfico, macroscópico e histológico nos dois grupos.Resultados: o adesivo de resorcina provoca: necrose do fragmento osteocondral em 100\% e 95\%, degeneração $90 \%$ e $100 \%$, corpo livre em $80 \%$ e $65 \%$ respectivamente no grupo I e II; comparado com a síntese metálica que apresentou: necrose em $25 \%$ e $35 \%$, degeneração $25 \%$ e $35 \%$, corpo livre em 35\% e $10 \%$ respectivamente no grupo I e II. Conclusão: o adesivo de resorcina, está relacionado com a necrose, degeneração cartilaginosa e despreendimento do fragmento osteocondral com maior freqüência que a síntese metálica

Descritores: Adesivos. Joelho. Coelho. Osteocondral. 


\section{Introduction}

The treatment of focal lesions of the cartilage to articulate with substance loss, it is still a challenge to the surgeons. The cicatrisation of these lesions happens, usually, with substitution of the cartilage for fibrous fabric or fibrocartilagem ${ }^{1}$. The substitution of the harmed area if she does for fabric fibrous scar and it carts to the medium and long period the degeneration to articulate, characterizing the osteoartrose $\mathrm{e}^{2}$. The difficulty for fixation of small fragments articulate happens for the inexistence of material of small dimensions and with enough resistance for the stabilization. The treatment usually proposed in these situations is the simple resection of the fragments with loss of the regularity of the surface to articulate, happening to the cicatrisation for fibrous fabric, with important alterations in morphology and operation of the articulation ${ }^{1-3}$. Among the procedures that try to accomplish fixation of the fragment he stands out: the use of the thread of Kirschner ${ }^{4}$, The use of the micro fragment ${ }^{4}$ screw, the cianocrilato adhesive, polimetilmetacrilato and the biological adhesive of $f$ fibrin $^{5}$. The cianocrilato ${ }^{6}$ adhesives, due to the long reabsorption period and for working as a barrier for the growth tecidual there is consensus that the cianoacrilatos ${ }^{6}$ should be avoided in this repairing ${ }^{6}$ type, the polimetilmetacrilato ${ }^{4}$ cement, presented with results little favorable ${ }^{4}$ and the fibrin glue, it was researched in orthopedics as only middle of adhesiveness presented resulted contradictory ${ }^{6,7}$. Known by the acronym GRF (GRF-glue-gelatin-resorcinol-formaldehyde) this adhesive, synthesized it starting from the eighties, it is formed by a composition the jelly base with resorcina, being polymerized for the addition of medicinal formaldehyde, forming a three-dimensional net with properties adhesives ${ }^{6}$ Has his application in the system digester $^{8}$, system respiratory ${ }^{9}$, and in the circulatory system, specifically in the aorta ${ }^{10}$. The three-dimensional formation checks to the resorcina adhesive a force tênsil that resists to the tensions produced in the suture of great vases as the aorta. It is also attributed to his/her force tênsil the good results in surgery on the traquéia ${ }^{9}$, usually also submitted to tractions, as well as in the digesting anatomizes in the presence of occlusions intestine's ${ }^{11}$. There are no reports in the biomedical literature researched on the use of this adhesive in orthopedics. For their characteristics of high resistance capacity to the force tênsil seemed pertinent the investigation of his/her application for fixation of small cartilage fragments in articulations sinoviais. The proposal of this research was to evaluate some morphologic aspects of the articulation of the knee in experimentation animal, when submitted the standardized defect of the cartilage to articulate and later fastened by the conventional method of osteossíntese (metallic synthesis) or with the adhesive to the jelly-resorcinaformaldehyde base.

\section{Methods}

The operative procedure was approved by the
Protocol 1261/03 of the Committee of Ethics of the Federal University of São Paulo-School From São Paulo of Medicine (UNIFESP-EPM), 80 rabbits of the lineage New Zealand, albino, males, 5 to 8 months of age, weight between 2600 and 3000 grams, coming of Central Biotério of the Federal University of Mato Grosso do Sul (UFMS). Aleatoriamente were distributed in I Group I $(n=40)$ continuation of the seven days and Group II $(n=40)$ continuation of the forty two days. The animals, they were raffled again in: subgroup $\mathrm{S}$ (metallic synthesis), subgroup G ("glue"-resorcinol sticker) and: subgroup C (it controls-that was the retreat of the fragment in the against-lateral knee to the operated).

\section{Operative procedure}

Accomplished antisepsis with solution of iodized alcohol $2 \%$ in both subsequent members and the placement of the cloths sterilized fenestrate, being isolated the knees. Digital traction of the skin in the anterolateral sense with objective of the operative scar to locate in the lateral face of the knee, preventing the contact of the skin operated with the soil and the walls of the cages. Incision of the skin and subcutaneous screen with $30 \mathrm{~mm}$ of length, in positioning lateral parapatelar, beginning to $10 \mathrm{~mm}$ proximal to the superior surface of the patella to the level of the epiphyses proximal of the shinbone, maintaining $10 \mathrm{~mm}$ of distance of the lateral border of the patella. Mechanical removal of the skin and subcutaneous screen with two afastadores in claw, identification and incision of $30 \mathrm{~mm}$ of length in the capsule to articulate lateral in the sense longitudinal ${ }^{8}$. Medial dislocation of the patella and of the extending muscular apparel for exhibition of the condylus femoral medial ${ }^{8}$. Flexing of the knee to ninety degrees, maintaining the patella dislocated medialmente. Identification of the origin of the subsequent ligament, taking her/it as the level of the osteotomia in the plan skull-flow in the condylus femoral medial ${ }^{8}$. It was taken as point of reference, the origin of the subsequent ligament that coincides with the leading edge of the osteotomia; starting from this point in subsequent direction in the condylus, he/she grew up a standard defect with $5 \mathrm{~mm}$ of length $\times 3 \mathrm{~mm}$ of width $\times 2 \mathrm{~mm}$ of depth in the border antero-interns of the medial femoral condylus . With a paquímetro, the distance of the center of the defect standard servant was measured to the apex of the sewage subsequent supracondiliana of the condylus femoral medial $^{8}$. To an electric perforator of controlled rotation, he/she joined a drill number 2 , denominated "he/she calls candle", with $20 \mathrm{~mm}$ of length and diâmetro ${ }^{8} 0,5 \mathrm{~mm}$. It was perforated two halfway holes amongst themselves in $3 \mathrm{~mm}$, and put to the about $1 \mathrm{~mm}$ of the borders, in the direction of the largest length of the standard defect, transfixed-if the fragment osteochondral resulting from the osteotomia. With a drill measuring $40 \mathrm{~mm}$ of length and $1 \mathrm{~mm}$ of diameter, he/she took place two parallel holes in the medial femoral côndylus, leaving of the standard defect, to $1 \mathrm{~mm}$ of the borders of larger length, towards the lateral face of the côndylus lateral ${ }^{10}$. In the animals raffled for application of the technique $\mathrm{S}$, the fragment 
osteochondral was fastened with 2 metallic pins (Figure 1). In the animals raffled for application of the technique $\mathrm{G}$, the fragment osteochondral was fastened with the sticker resorcinol (Figure 2). For the control (technique C), the fragment osteochondral was simply solitary of the knee contra lateral staying the defect standard vazio ${ }^{8}$. Mechanical cleaning of the cavity to articulate with isotonic saline solution of chloride of sodium $0,9 \%$, following by hemostasis compressive. Reduction of the patella and of the extending muscular apparel. Closing of the capsule to articulate with four simple points, separate with thread of suture polidioxanona (PDX) 00 and of the subcutaneous screen and of the skin in only plan, with continuous suture of thread of polyamide monofilament 5.0. The operative wounds were left discoveries, the operated members did not receive any immobilization type expresses, with the purpose of observing the behavior of the synthesis, and the use of antibiotic prophylactic was spared. For the anesthetic recovery, the rabbits were returned to their cages staying wrapped up for the operative cloths to avoid loss of corporal heat. The rabbits were submitted to exam radiographic for mensuration of the angle of extension of the Knees or angle femoro-tibial in extension of the knees, in the pré and postoperative.

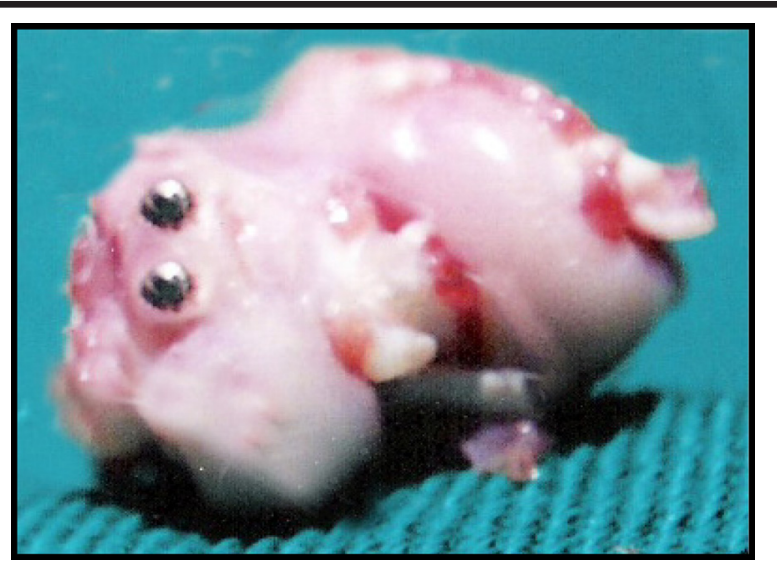

FIGURE 1 - I Fragment osteochondral put back at her bed with the 2 pins transfixed crossing the cortical lateral of the lateral femoral côndylus.

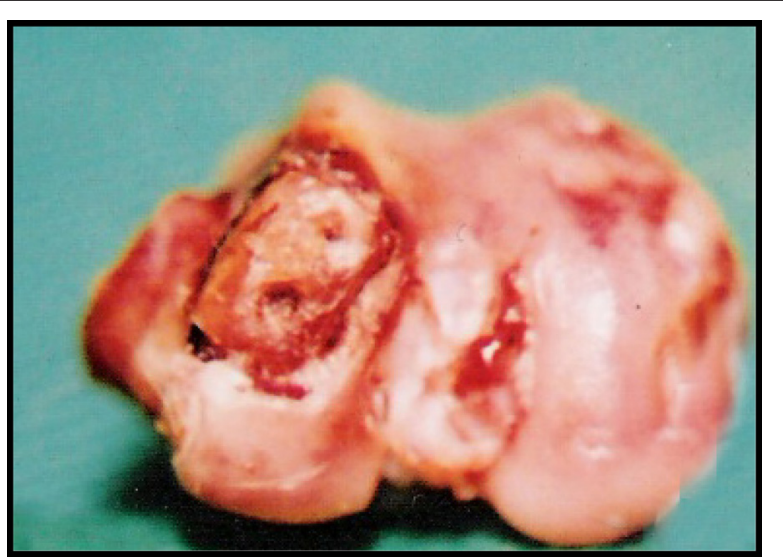

FIGURE 2 - Fragment osteochondral fastened at her bed with the resorcina adhesive.

\section{Mensuration Radiographic}

For standardization of the lines that they give origin the measure of the angle femoro-tibial, she preceded the sequence shown in the Figure 3:

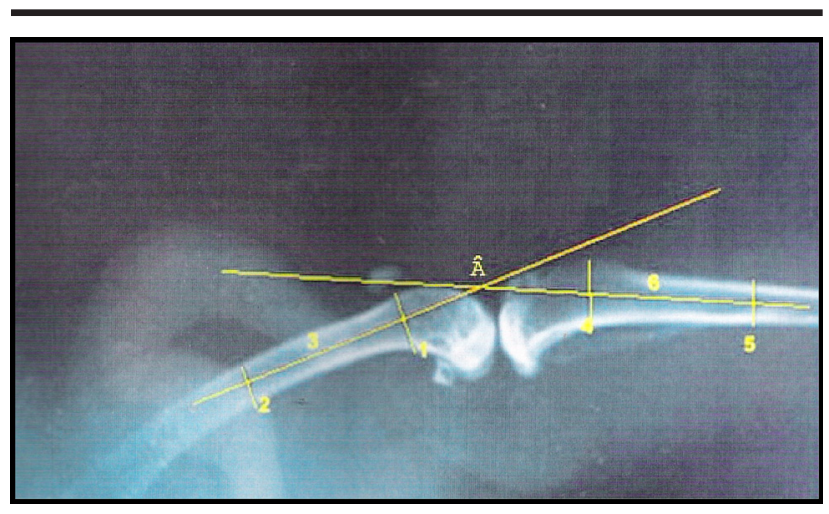

FIGURE 3 - Method of mensuration radiographic of the angle of extension of the knee (Â).

(1) Perpendicular line to the cortical previous of the femur;

(2) Parallel line to the (1) distends $30 \mathrm{~mm}$ of the same;

(3) Longitudinal line drawn by the medium points of the lines (1) and (2);

(4) Perpendicular line to the cortical subsequent of the shinbone;

(5) Parallel line to the (4) distends $30 \mathrm{~mm}$ of the same;

(6) Longitudinal line drawn by the medium points of the lines (4) and (5).

(Â) Extension angle

\section{Study Macroscopic}

They were logged the following parameters: observation of the cartilage to articulate, in relation to the color, integrity, observation of the presence of free bodies articulate, observation of the synthesis of the fragment osteochondral fastened with metallic pins or with adhesive of jelly-resorcina-glutaraldeído.

\section{Study microscopic}

Habitual technique of histological preparation and coloration hematoxilina and eosina (HE) and tricômico of Gomory. In the microscopic analysis, accomplished by three pathologists, the following parameters were observed: degeneration of the cartilage hyaline, observation of presence of bone and cartilaginous necrosis.

\section{Statistical analysis}

For statistical analysis of the results, accomplished by the Discipline of Biostatistics of the Department of Preventive Medicine of UNIFESP - EPM, parametric tests and no-parametric tests were used, being taken into account the nature of the studied variables. They were applied the following tests: it Tests of the quiquadrado. Test of MannWhitney. Test of Wilcoxon; it Tests " $t$ " of Student. 


\section{Results}

\section{$\square$ Adhesive $\square$ Synthesis $\square$ Control/Adhesive $\square$ Control/Synthesis}

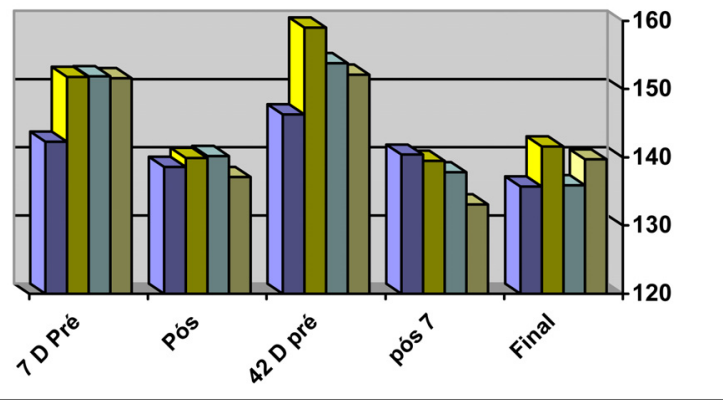

FIGURE 4 - Distribution of the averages of the angles of extension of the knees of rabbits of the Groups I (7 days) and II (42 days), measured in the X-rays in the pré and postoperative, in the different study sub-groups.

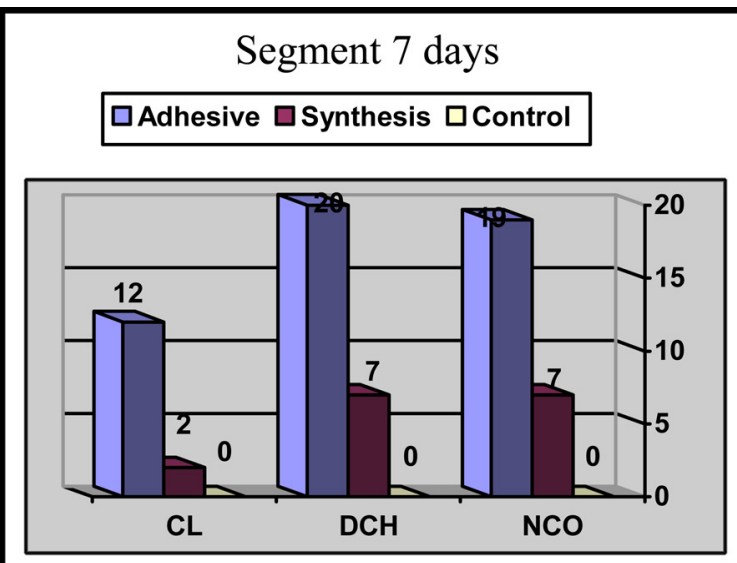

Segment 42 days

\section{$\square$ Adhesive $\square$ Synthesis $\square$ Control}

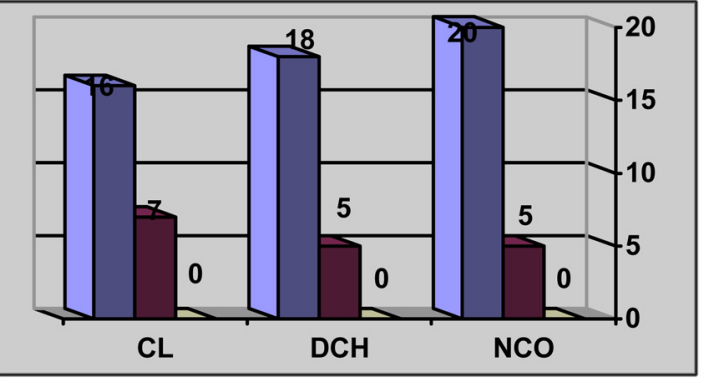

FIGURE 5 - C L = free body, D C H = degeneration of the cartilage hyaline, $\mathrm{N} \mathrm{C} \mathrm{THE}=$ it necroses of the cartilage hyaline /osso subchondral.

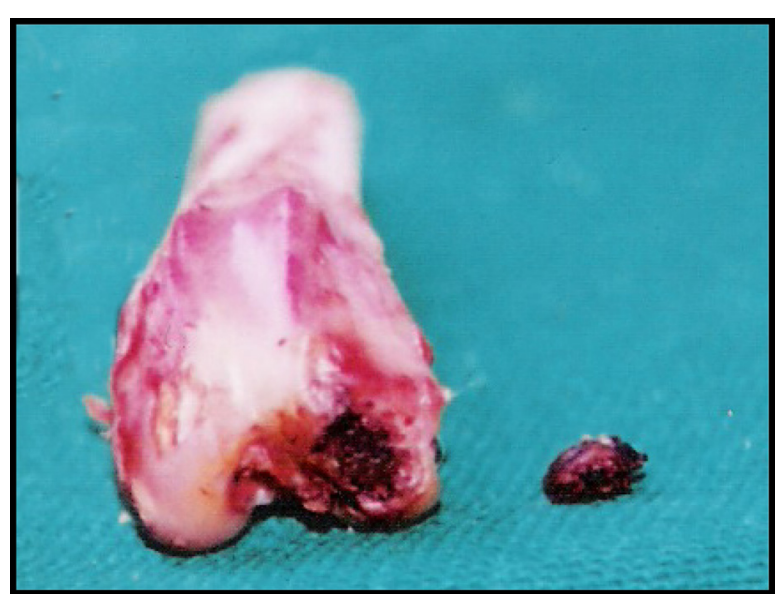

FIGURE 6 - Resorcina sticker with fixation flaw, presenting $\checkmark=$ bed empty osteocondra $\downarrow=$ free body.

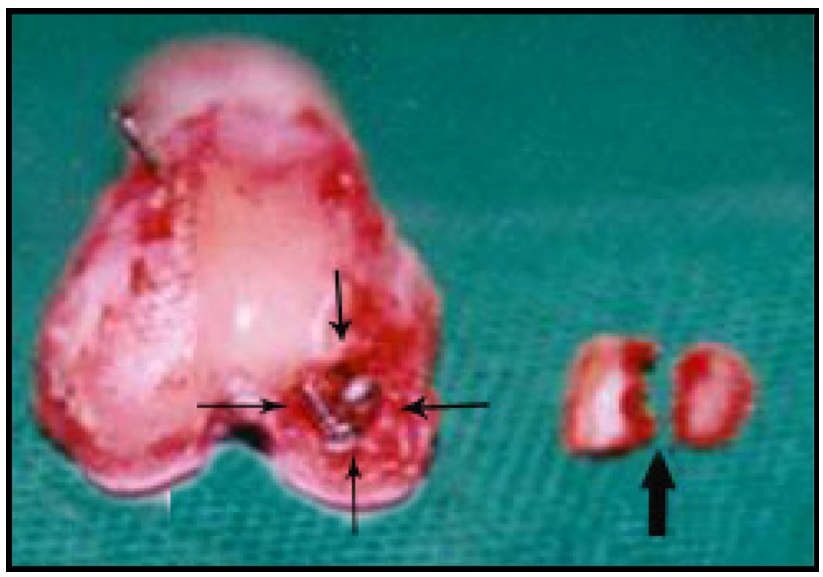

FIGURE 7 - Metallic synthesis with fixation flaw, presenting free body. $\downarrow$ = bed osteochondral with metallic pins, $\boldsymbol{\uparrow}=$ body free with longitudinal fracture.

\section{Discussion}

The lesions of the cartilage to articulate, he/she wants degenerative or traumatic with loss of it nourishes, they are fearsome for the surgeon orthopedic specialist in reason of the low capacity of regeneration of this fabric. His/her substitution for woven fibrotic cicatricial takes, in the great majority of the times, to a functional compromising with all their painful clinical manifestations and/or incapacitantes ${ }^{1}$. In the articulations sinoviais the cartilage sinovial is sustained partly in their nutritional and regenerative aspects for the is liquidate sinovial. His/her capacity to maintain integral text and to answer with regenerative process depends, however, of the integrity of the bone sub-chondral ${ }^{1}$. In general there is consensus that small fragments, which she do not get to fasten, they can be removed of the articulaçãol. The repairing or cicatrisation of the remaining cartilage provokes damages of 
small sets up, although with repercussions clinical, temporary or definitive, of pain to the limitation functional variável ${ }^{1,2}$. More extensive lesions are associated to processes fibrotic cicatriciais and morphologic compromising and funcional ${ }^{1,2}$. The repair of the lesions of the cartilage to articulate it has been studied thoroughly and several proposed they are available. The fixation of the outstanding fragment is the most frequent proposition. The fixation procedures involve different techniques and materials ${ }^{4}$. In the literature it is proposed the use of metallic threads or synthetic's ${ }^{4,5}$, metallic pins or of material degradável ${ }^{4}$, biological adhesives or synthetic's $\mathrm{s}^{4,7}$, among others. In the most extensive lesions they exist proposed of using cartilage solemnity-graft or homoenxerto ${ }^{4,12}$. The fixation in mosaic ${ }^{13}$ or of larger fragments he/she has their results harnessed to the use of the applied technique. The fixation way of the fragments to the receiving bed is important factor in the evolution of the doença ${ }^{12,13}$. Like this, it has been seeking alternatives in the genetic engineering, transplant's $\mathrm{s}^{14}$ or biomaterials. In addition, one have been studying substances that can induce or to stimulate the cartilaginous regeneration, although these studies are still in phase initial ${ }^{15}$. Most of the propositions end for dashing in the need of fastening a cartilaginous fabric on the area lesada ${ }^{13}$. The revision of the biomedical literature showed several works with the use of surgical adhesives, in the great majority to the fibrin base, the call glues biologic $c^{4,6,7}$. Because of the use diversity and application techniques a consensus idea cannot be removed. There are favorable and unfavorable results, but as the used methodology it differs the conclusive analysis is prejudiced $^{4,6,7}$. The derived synthetic adhesive of the cianoacrilato, for having a polymerization exothermic, it has not been presenting satisfactory results in cartilage or osso $^{4,6}$. There are no reports of the use of a type of known adhesive as "it glues French" ("French glue"), a composition the jelly base, resorcinol and glutaraldeído (formaldehyde), in orthopedics, to not to be for fixation of bone fragments in surgeries facials ${ }^{6,8,9,11}$. The use of this adhesive in woven of the windpipe and arteries has been demonstrating that his/her threedimensional architecture to the it produces polymerize-her an adhesiveness that supports the rupture ${ }^{9,10}$ forces better. The manufacturer recommends his/her job in cardiovascular surgery, general surgery, neurosurgery, otorhinolaryngology, urology, ophthalmology and dentistry. This way it seemed interesting the proposal of use of this product in the fixation of cartilage fragment to articulate in experimentation animal. The application of the adhesive did not present technical difficulties. For they be products hidrossolúveis, before the mixture, the manipulation of the flasks was easy. After the mixture the adhesive effect began to manifest in up to two minutes, enough time for his/her appropriate application and eventual removal of the excess of applied substance. The subsequent limpeza with saline solution removed all and any possibility of permanence of residues of the adhesive in the receiving bed or inside of the articulation. To test the validity of the use of the resorcinol adhesive an animal model of disease it was used idealized by Inouye ${ }^{4}$. The model in rabbits creates a defect osteochondral standardized in the surface to articulate of the knee in support area, with dimensions $5 \times 3 \times 2 \mathrm{~mm}$. It demonstrated the adaptation of this model for the simulation of a situation of loss of substance of cartilage osteochondral in articulation sinovial. He/she used the polidioxanone thread (PDX) and the metallic fixation showed that the fixation with thread synthetic abortively is a possibility viável ${ }^{4}$. He/she did not take place any immobilization procedure due to the operational difficulty of maintaining the animal with a splint or I equip gessado, especially in considering that the immobilization should be bilateral, inside of the proposed model. Unilateral immobilization would demand a larger number of animals than inconvenience was considered by the Commission of Ethics. He/she was also considered that the model previous of Inouye the immobilization was unnecessary and he/she did not have influence in the results obtidos 4 . For comparison of the fixation technique with adhesive she opted for the metallic fixation that it is a procedure of average use in these situations. The daily observation of the animals for the tratador, veterinarian and researcher did not surprise any aspect to be worthy of note or that could interfere in the appraised parameters in the research. The measure of the extension angles in the preoperative period compared with the postoperative periods to the seven and forty of two days showed that there are no significant differences among the animals that had the fragment fastened with adhesive, with metallic synthesis or that you/they had the removed fragment. In all of the groups the extension angles were larger in the preoperative period. (Figure 4) Any that is the employed technique happened a loss of extension of the knee of the animal in relation to the preoperative situation. It was not possible to establish a difference among these measured that can be attributed to one of the employed techniques. All take the loss of movement of extension of the knee equally. The technique with the adhesive use showed indexes of detachment of the fragment by eighty percent of the cases in seven days and in seventy five percent to the forty two days (Figure 6, graph 2 and 3). The technique of metallic synthesis showed detachment of thirty five percent to the seven days and ten percent to the forty two days of observation (Illustration 4, 5 and 6). The resorcinol adhesive in the studied model was shown very inferior in terms of fixation of the fragment than the technique of metallic synthesis. One of the reasons fanned to explain the high detachment incidence would be the lack of immobilization of the operated member, what could happen a precocious detachment of the fragment. Some works told in the literature with use of biological adhesive do reference the immobilization in the initial apprenticeships of the observation, although most of the works does not make mention of the use or not of imobilização $0^{3,4,7}$. In that it weighs to the immobilization lack the adhesive was shown unable of by itself of maintaining the fastened fragment and, therefore his/her applicability is in the dependence of other specific evaluations for his/her adhesiveness capacity. Among other options it would be to the immobilization need or study of the adhesive as adjuvant of other fixation means. Analyzing the other microscopic parameters can be observed that in the group of the animals that you/they received the adhesive happened larger degeneration of the cartilage hyaline and bone subchondral and larger presence of necrosis of the cartilage hyaline and bone subchondral simultaneously (Figure 4and 5) The analysis together of these parameters it is coherent with a harmful action of the adhesive on the biological fabric. The presence of the adhesive seems to have provoked a lesion more extensive tecidual than that restricted one the provocation of the defect. The metallic synthesis in these same microscopic parameters was shown much closer to the of the group it 
controls. The presence of the metallic body also provoked degeneration and necrosis of the cartilage hyaline, but in proportion very inferior to the adhesive and close to the data of the group it controls. The global analysis of the results allows to end that the manipulation of the articulation of the knee in any of the used procedures takes to a functional compromising, acted by the decrease of the flexing angle and inadequate repair of the lesion osteochondral, acted by the alterations macro and microscopic observed. The retreat of the fragment provokes a more compromising lesion than the fixation attempt, what is compatible with the results of other works in the literature ${ }^{1,4,5,12}$. In comparison with the fixation with the metallic synthesis of the fragment the adhesive to the jelly base, resorcinol and glutaraldeído inferior was shown. The option of the exclusive use of a adhesive continues being challenge for the fixation of cartilage fragment to articulate. The fixation with metallic material produces better results than the simple removal of the fragments ${ }^{5}$, and in the case I specify of this research better results than the adhesive use. The model experimental utilized ${ }^{6}$ showed his/her adaptation once again and susceptible to be used in other experimental works, besides to test other adhesives as exclusive use of fixation or supporting of other types and fixation materials.

\section{Conclusions}

The adhesive of jelly-resorcina-glutaraldeído it was not shown appropriate for fixation of cartilage fragment to articulate in a defect osteochondral provoked in rabbit knee. The metallic synthesis of cartilage fragment to articulate it is more appropriate than his/her simple removal of the articulation of the rabbit knee.

\section{References}

1. Salter RB. Disturbances and lesions of the system skeletal muscle. 3ed. São Paulo: Medsi; 2001.

2. Athanasiou KA, Shah AR, Hernandez RJ;,LeBaron RG. Basic science of to articulate cartilage repair. Clin Sports Med. 2001;20(2):223-47.

3. Hisatome T, Yasunaga Y, Ikuta Y, Fujimoto Y. Effects on to articulate cartilage of subchondral replacement with polymethylmethacrylate and calcium phosphate cement. J Biomed Mater Cattle. 2002;59(3):490-8.
4. Inouye CM, Fagundes DJ, Faloppa F, New NF, Juliano Y, Figueiredo THE, Taha MÓ. I study morphologic of the articulation of the knee of rabbits after the reparaçäo of a defect osteochondral. Acta Cir Bras. 2002;17(6):403-9.

5. Stubbs M, Zhang H, Vrahas MS, Baratta RV, Zieske A. Effect of intraarticular stainless steel implants on the health of the rabbit knee joint: an experimental study. J Orthop Trauma 2000; 14(8):567-70.

6. Fagundes DJ, Taha MÓ, Rivoire HC. Surgical adhesives: revisäo and atualizaçäo. J Bras Med. 2002;82(3):101-3.

7. Arun K, Gosain J. The current status of tissue glues goes cap fixation. Plast Reconstr Surg. 2001;2:2581-3.

8. Medeiros AC, Ramos CCF, Freire TMGL, Pinto Jr FEL, Medeiros PJ, Mello, Azevedo, FC Uso again surgical adhesive in anastomoses of the lap. I study experimental in mice. Acta Cir Bras. 1990;5(4):136-40.

9. Takahashi N, Ichimiya Y, Mawatari T, Kusajima K, Komatsu S. The reinforcement of tracheoplasty with the self-fascia Gelatin-Resorcin-formal and barks (GRF) glue. Surg Today. 1997;27(11):1046-50.

10. Unlü Y; Vural U; Koçak H; Ceviz M; Becit N; Akbulut Comparison of the topical haemostatic agents goes the prevention of sutures hole bleeding. An experimental study Eur J Vasc Endovasc Surg. 2002;23(5):441-4.

11. Biondo-Simöes MLP, Koppe GL, Hansel H, Rosário MAK, Malafaia O. I use of biological adhesive in intestinal anastomoses: I study experimental in dogs Acta Cir Bras. 1992;7(4):151-3.

12. Navarro R, Cohen M, Filho MC, Silva RT. The arthroscopic treatment of osteochondritis dissecans of the knee with autologos cap sticks. J Arthoroscopic. 2002;18(8):840-4.

13. Hangody L, Feczkó P, Bartha L, Bodó G, Kish G. Mosaicplasty goes the treatment of to articulate defects of the knee and ankle. C Orthopaedics. 2001;391:328-36.

14. Peterson L, Kiviranta I? kerlund EL. Autologus chondrocyte transplantation. Am J Sports Med. 2002;30(1):2-11.

15. Hidaka C, Goodrich LR, Chen CT, Warren RF, Crystal $\mathrm{RG}$, Nixon AJ. Acceleration of cartilage repair by genetically modified chondrocytes over expressing cap morphogenetic protein-7. J Orthop Cattle. 2003;21(4):573-83.
Correspondence:

Augusto Sakihama

UNIDERP

Rua Alexandre Herculano, 1400

Chácara dos Poderes

79 0370-280 - Campo Grande - MS - Brazil
Conflict of interest: none Financial Source: none

\section{How to cite this article:}

Sakihama AK, Fagundes DJ, Inouye CM, Aydos RD, Juliano Y, Arakaki JC, Odashiro M, Carvalho PTC. The use of resorcine adhesive in repairing osteochondral's defect in knees of rabbits. Acta Cir Bras. [serial on the Internet] 2006;21 Suppl 4. Available from URL: http://www.scielo.br/acb. 